\title{
"Mirando las cosas de cerca": Indigenous Marriage in the Philippines in the Light of Law and Legal Opinions (17th-18th Centuries)
}

\author{
Marya Camacho
}

When authorities, both ecclesiastical and secular, in the early colonial Philippines had to grapple with questions related to marriage, they could count on analogous experiences in Spanish America and how Church law had been applied there, as well as on the law of the Indies, depending on which aspect posed a problem. In the process, they legislated for the specific local circumstances of the Philippines and solicited opinions from moral theologians, who deliberated with prudent consideration of local custom. This chapter inquires into the mediating role of law, legal opinions, and moral cases in the attempts to reshape indigenous marriage: primarily, the interpretation and translation of indigenous notions and customs to Spanish, Catholic normative concepts and practices, which were strongly imbued with the Council of Trent; and, to some extent, the modes of negotiation and indications of assimilation. Specifically, it examines selected writings of two Dominicans - mainly the legal opinions or consultas of Juan de Paz from the 17th century and moral cases by Francisco Martínez from the late 18th century - in two aspects: the application of European sources to Philippine questions and their contextualisation in local laws and institutions. The consultas and moral cases selected for this paper pertain less to canonical marriage and more to marriage-related questions with distinctively indigenous features. They constitute cases of normative encounter in the realm of canon and civil law and moral theology. They present examples of the local application of the legal and theological repertoire used in early modern Spain. In effect, they were an important channel by which European categories and praxis were embedded in the performance of justice in a context different from the referent. Wherever possible, historiographical illustration of the process of negotiation between the normative orders complements the theoretical discussion in the consultas and moral cases. 
This chapter analyses the discourse of Paz and Martínez with respect to the moral and juridical perspectives they took, and thereby the authors they cited, particularly those related to the School of Salamanca. These writings reveal the kind of intellectual formation that was shared in the early modern Iberian universities and colleges in which the two Dominicans were educated. The cases discussed in this chapter illustrate the existence of "colonial scholasticism", understood both as an epistemic community and as a community of practice that Thomas Duve posits in his introductory chapter. Indeed, the genealogy of the Dominican University of Santo Tomas de Manila, where Juan de Paz was a professor for many years and which exercised the corporate function of a moral and juridical consultant in the colony, can be traced unequivocally to the Spanish academic tradition. For the formation of its own members, the Dominican province in the Philippines maintained the practice of writing moral cases, of which Francisco Martínez's surviving work is an erudite example. The works of Paz and Martínez demonstrate the polycentric nature of what would later be called the School of Salamanca: in the Philippines, the School's characteristic mode of knowledge production and its pragmatic dimension found new applications.

The University of Santo Tomas de Manila: Foundation and Character

In the early years of the Philippine colony, the Dominican province had no stable centre for its institutional studies, simply providing classes for the younger members who came to Manila without having finished their studies in Spain or Mexico. Some Dominicans who came had left their teaching positions in Spain. Because of the pressing need, however, masters and students were sent to the field as missionaries after they had completed their formation. But the Dominican Miguel de Benavides, third archbishop of Manila, was not happy with that situation. As the Dominican chronicler Diego Aduarte explained, Benavides considered the formation of priests as an "architectural" task, preceding the work of evangelising and an essential prerequisite for it. He himself had been a colegial in San Gregorio in Valladolid and was known to be a favourite student of Domingo Báñez. ${ }^{1}$ Evidence of this belief was the fact that, following the establishment of the colegio-seminario, clerical benefices began to be filled by better qualified individuals equipped with the appropriate

1 Ocío and Neira, Misioneros dominicos, vol. 1, 43 . 
studies. In his last will, Benavides left a donation for the future establishment of a centre of learning for grammar, philosophy (artes), and theology for religious and lay students. When additional funds had been gathered, the Colegio del Santísimo Rosario was founded in 1611 with 12 lay students. ${ }^{2}$ In 1619 , the first papal bull was promulgated which temporarily conferred the authority to grant degrees to the colegio. Aduarte proudly described the academic level of the colegio,

Se començó el estudio con mucha formalidad, y tanto cuydado, y diligencia, como en los muy aventajados de España, porque los Letores, y Retor, eran todos criados, en ilustres estudios de nuestra Religion, y pusieron las liciones, conferencias, y demás exercicios del estudio, como los que avian cursado en España. ${ }^{3}$

Towards the end of the 17th century, the Dominican chronicler Baltasar de Santa Cruz likewise reported that among the merits of the new university was the formation of learned persons who had since occupied ecclesiastical posts in both Manila and New Spain, including bishoprics. ${ }^{4}$

By 1639 the Dominican province sought to convert the existing colegio into a university to be able to maintain the privilege of granting degrees. ${ }^{5}$ It obtained a letter of petition from Philip IV that was to be presented to Pope Innocent $\mathrm{x}$ for this reason. The apostolic brief In Supereminenti issued on 20 November 1645 created the university in the premises of the colegio $^{6}$ until such a time that a studium generale could be established. ${ }^{7}$ The Apostolic See had taken into consideration the vast distances between Manila and Mexico and Peru,

2 Villarroel, A History of the University of Santo Tomas, 37-43. According to the act of foundation, its name was Colegio de Nuestra Señora del Rosario, but the Dominican chroniclers Diego de Aduarte and Baltasar de Santa Cruz referred to it as the Colegio de Santo Tomás. Villarroel explained that the two names were used alternatively by the Dominican provincial chapters until 1623, after which Santo Tomás was retained.

3 Aduarte, Historia de la Provincia del Santo Rosario, 48o-481.

4 Santa Cruz, Historia de la Provincia del Santo Rosario, 169-172.

5 An important context of this petition is the existence of other colegios in Manila. Villarroel, A History of the University of Santo Tomas, 99-116.

6 On the distinction between the juridical entity of the university and the colegio which provided the material structure and wherewithal, see González González, El poder de las letras, 127-128 and Villarroel, $A$ History of the University of Santo Tomas, 117-118.

7 For a translation of the apostolic brief, see Villarroel, A History of the University of Santo Tomas, 107-108. 
where universities were located. ${ }^{8}$ The next immediate step was to formulate the university statutes. The chronicler Santa Cruz explained the genealogy of the statutes of the university,

el estilo, y practica de la Real Universidad de Mexico (de quien desde sus principios se ha Preciado de ser muy hija, y en quien ha hallado los honrosos oficios de generosa Madre con comercio de Cartas, y favores que le ha hecho) ... siendo de la dicha su Real, y siempre Noble Madre, que los determinó por el estilo, y forma de la celebérrima de Salamanca. ${ }^{9}$

These statutes were sent to Mexico in 1649 to be examined to see whether they conformed to the latter's constitutions. The following year, the Santo Tomas wrote to Mexico "suplicando se sirvan de admitirnos debajo de su protección, enviando sus Estatutos, privilegios e inmunidades, para que acá se guarden recibiendo esta Universidad por hija suya y a sus graduados". This request was granted in $1652 .{ }^{10}$ At the time of the request, the University of Mexico was in the process of a transition, with the statutes of Bishop Juan de Palafox still under review in Madrid. ${ }^{11}$ The records show that Manila followed up on the matter of regulations but are silent on the outcome of this request. ${ }^{2}$ Contributing to this lacuna is the fact fact that there is no extant archival copy of the statutes of the newly erected university or of the original ones of the colegio. ${ }^{13}$ Nonetheless,

8 For the context of the initiative to petition for university status, see Villarroel, $A$ History of the University of Santo Tomas, 104-110; on the question the studium generale, 115-116.

9 Villarroel, A History of the University of Santo Tomas, 172.

10 Santamaría, Estudios históricos, 75-77. Archives of the University of Santo Tomas, Manila (AUST), Libros, t. 51, fol. 96v. The Santo Tomas sent an ivory figure of Christ to Mexico as a token of gratitude for the institutional adoption: "El aver admitido por hija essa illustre Universidad de Mexico a esta de Sto Thomas de Manila se deve a la solicitud de V.P.M.R. el aver escrito su Claustro a su Magestad (que Dios guarde) dandole las gracias de su ereccion, a su cuidado y diligencia [...]". The archives of the University of Santo Tomas conserve 14 letters from 1649 to 1655 that were exchanged between the two institutions expressing the desire to strengthen their relationship. Villarroel, A History of the University of Santo Tomas, 115 .

11 AUST, Libros, t. 51, 89r-89v. The recent work of E. González and V. Gutiérrez (Juan de Palafox $y$ Mendoza, 40-47) may well provide an explanation for the apparent silence - unless some of the correspondence has been lost - in the controversies surrounding Palafox's Constituciones which were completed in 1645 and received royal approval in May 1649.

12 There is no extant copy of these statutes and there are no further revisions on record until 1734. Villarroel, A History of the University of Santo Tomas, 118-119.

13 Villarroel, A History of the University of Santo Tomas, 45. In the absence of a copy, Santamaría musters documentary evidence to confirm that the original statutes were the same as those of Mexico. Estudios históricos, 71-73, drawn from AUST, Libros, t. 37. 
documentation on the formation of the statutes of 1775 confirmed that the old statutes were based on those of Mexico and Salamanca. ${ }^{14}$

Similarly, in the absence of the statutes, academic life has to be reconstructed from other contemporary sources. In Philip IV's petition to the Holy See to erect the university, the models proposed were the Dominican universities in Ávila and Pamplona, as well as those in Mexico and Lima. ${ }^{15}$ Following the European universities, the study of philosophy at the Colegio de Santo Tomás was Aristotelian-Thomistic and the method of teaching was the same as in Spain, with professors reading and commenting on canonical texts. Theological studies followed St. Thomas Aquinas's Summa with morning classes (prima) on dogmatic theology and moral theology in the afternoon (vespers). The books preserved in the archives and library of the University of Santo Tomas attest to the curriculum. ${ }^{16}$ The collection includes not only the canonical texts of Aristotle, Peter Lombard, and St. Thomas Aquinas, but also commentaries on them and on civil and canon law, as well as other doctrinal works based on Thomism. Authors of the School of Salamanca are prominently represented, with editions of their works dating from the 16th to the 18th centuries. ${ }^{17}$ Unfortunately, the lecture notes, which must have been abundant, and many other written works on philosophy and theology have not been preserved, partly the result of scarce printing activity throughout most of the 17th century. In his History of the University of Santo Tomas, Fidel Villarroel surmised that the curriculum did not undergo great changes upon the colegio's conversion to university. The academic exercises required to obtain degrees were modelled on those of Mexican and Spanish universities. ${ }^{18}$ As a Dominican institution, the teaching staff, composed of lectores, was appointed by the provincial chapters, and adhered to the teachings of Aquinas in accordance with the Dominican constitutional mandate. The actas of the annual provincial

14 AUST, Libros, t. 54, fol. 11v.

15 Villarroel, $A$ History of the University of Santo Tomas, 18-19.

16 Villarroel, $A$ History of the University of Santo Tomas, 67-73, including the endnotes which detail the books corresponding to the courses, extant in the current collection of the University of Santo Tomas.

17 Aparicio and Majuelo, Catalogue of Rare Books, vols. 1-2; Villarroel, "The University of Santo Tomas Library", 76-8o and 89-9o.

18 AUST, Libros, t. 37. An example of the record of required final academic exercises as well as the rite of conferral of the degree in this period is that of Fr. Agustin Garcia, AUsT, Becerros, t. 1, fols. $3^{r}-4$ r. Villarroel explained that without an extant copy of the first university statutes, we cannot have accurate knowledge of different aspects of university life, such as the academic program and student activities. One can only assume similarity to universities in Spain and America in that period, A History of the University of Santo Tomas, 121-122. 
chapters consistently recorded the appointment of lectores for the prima and vespers of theology, and those for the arts and humanities. ${ }^{19}$

The other indicator that the academic tradition continued was the fact that the rectors and professors themselves - during the 17 th century - had been educated in institutions that thrived in the Spanish theological movement that had its centre in the University of Salamanca. Among those who became rectors, six were colegiales of San Gregorio in Valladolid: Baltasar Fort, who studied under Domingo Báñez, Francisco de Herrera, Domingo Fernández Navarrete, Martín Real de la Cruz, Felipe Pardo, Pedro de la Fuente, and Francisco Sánchez. Likewise, a number of professors were educated there: Jacinto Esquivel del Rosario, Juan López Galván, Luis Álvarez, Francisco de Miranda, José de Isusi, and Juan Romero. Only two rectors came from San Esteban in Salamanca, Francisco de Paula and Manuel de Mercadillo, and two professors have been identified as having been educated there, Alonso Sandín and Francisco Antonio de Vargas. A theology professor by the name of Miguel Osorio was colegial in Alcalá. The other rectors and professors were schooled in different Dominican conventual colegios, such as Santa Cruz in Granada, San Pablo in Seville, Santo Tomás in Alcalá, San Pedro Mártir in Toledo, and Santo Tomás in Seville. Raimundo Berart was an exception, having completed his studies in civil and canon law at the Universities of Barcelona and Lérida. ${ }^{20}$

\section{The University as the Source of Opinions on Legal and Moral Cases}

As Dominican chroniclers well recorded in the biographies of their confreres in the Philippines, no one was confined to one assignment during their time there. Those who were assigned teaching and administrative positions in the university could combine it with pastoral work or other offices that required their expertise, such as that of commissary of the Holy Office. They also spent some years in missions and the administration of parishes, and some were assigned to governance positions in the Dominican province. Francisco de Acuña explained that the consultas of his mentor Juan de Paz's had not yet been published in Manila because there was no one who could be spared to take charge of the time-consuming publication process, considering that there were relatively few Dominicans for the tasks that were considered more pressing, not to mention the daily regimen of prayer to which they were bound. ${ }^{21}$

19 Acta Capitulorum, from the year 1647 to 1698 , section Asignaciones.

$20 \quad$ Ocio and Neira, Misioneros dominicos, vol. 1.

21 Acuña, "Carta dedicatoria" in Paz, Consultas y resoluciones varias. The lengthy description of the concerns of the Dominicans in the Philippines and complaints about the 
Corporately and individually, the Dominicans, as well as the other religious orders present in Manila, received consultations on moral and legal (canon or civil law) cases (consultas) from public officials and governance bodies, and from private institutions and individuals. In response, moral theologians wrote their opinion or exposition on the matter at hand. In the current state of conservation of the resulting documents titled pareceres $y$ respuestas, it is sometimes the case that the works of several persons are bundled together but attributed to one author, as has presumably happened with those of the famed moral theologian Domingo González. ${ }^{22}$ That their work became an important reference for moral theology applied to local scenarios is indicated in the 1648 provincial chapter's approval of the request to compile "respuestas y resoluciones" by González, who had died the previous year, "para direccion y luz de otros muchos casos y dificultades, que se fueren ofreciendo". The rector of the colegio of Santo Tomás was put in charge of making copies of the compilation which were then to be distributed to provincial vicars. ${ }^{23}$

In light of the above, the directive of the provincial vicar Bartolomé Marron recorded in the provincial chapter of 1684 -, which favoured collegial opinions over exclusively individual pareceres, marked a sharp turn. He had previously imposed this rule during an earlier visitation to the Santo Tomás, and was now extending the precept so that all individual opinions had to be discussed with the provincial or, in his absence, the provincial vicar, and signed by the majority of the lectores of the university. ${ }^{24}$ In the 18th century, a more organised manner of keeping the opinions and cases for future reference was the libro de consultas, which was compiled by the rector Juan Fernández (1774-1777). ${ }^{25}$ Each case was signed by the professor who studied it, or by several if it was done collegially. In the university archives, these texts were sometimes mixed together with those of other genres, such as homilies and treatises, like those attributed to Francisco Martínez which were probably written at the turn of the 18th century. ${ }^{26}$ By the late 17 th century, no compilation of pareceres written in the Philippines had yet been published in book form for wider circulation. The Consultas y resoluciones varias teológicas, jurídicas, regulares, y morales of Juan de Paz was the first, according to his former student Francisco de

ineptitude of local printers were central to the appeal to the Colegio de Santo Tomás in Seville to accept the task of publishing the Consultas of their eminent alumnus.

22 Velasco, "Apuntes", $5^{26 .}$

23 Acta Capitulorum, vol. 1, 224.

24 Acta Capitulorum, vol. 1, 377.

25 For the 17th and 18th centuries, see AUST, Becerros, t. 25 and 26.; AUST, Libros, t. 20.

26 AUST, Libros, t. 62. 
Acuña, even though other theologians like Domingo González (1574-1647) and Sebastián Oquendo (1599-1651) had preceded him in producing that genre. ${ }^{27}$ This mass of opinions represented the institutional function of the university - as Salamanca and others in the Iberian world had likewise assumed - to provide expert opinions drawn mainly from moral theology. Ultimately, the university as a moral entity took responsibility for the replies that individual professors offered.

Duve's exposition of the theory of practice at the beginning of this volume obviates the need for further elaboration of the method followed by the Dominicans in Santo Tomás. The combined application of auctoritas and ratio to specific cases in order to arrive at the solution is clearly demonstrated in the cases analysed below. ${ }^{28}$ Aside from the obvious weight of civil and canon law, the commentaries of authoritative authors heavily guided the task of finding the solution deemed most just and prudent.

Juan de Paz spent most of the years that he lived in the Philippines as an academic. He was a lector in philosophy and theology both in the Dominican convent and in the university. He occupied governance posts in different periods: rector and chancellor of the university, prior of the Dominican convent in Manila, and provincial vicar. His renown for sound moral and legal opinions earned him fame as an "oracle". Contextualised in the Iberian cultural practice of consultation which Duve mentions in his introductory chapter, the weight of Juan de Paz's opinions in colonial society may be appreciated more fully. According to his biographer Vicente Salazar, aside from the unerring quality of his pareceres, his humility and diligence were noteworthy, and he served everyone with equal promptness and thoroughness without expecting any compensation. Among those who consulted him were bishops and provincials of other religious orders, corporate bodies such as the cathedral

27 Acuña, "Carta dedicatoria", in Paz, Consultas y resoluciones varias.

28 Regarding the weight of auctoritas, see also Tau Anzoátegui, El jurista en el Nuevo Mundo, 102-105.

29 A native of the province Córdoba in Spain, he professed in the Convent of San Pablo in Córdoba in 1638 and studied at the Colegio de Santo Tomás in Seville where he became a lector in philosophy. While there, he decided to join the 1648 Dominican mission to the Philippines. For his earliest biography, see Salazar, Historia de la Provincia de el Santísimo Rosario, 729-731; also Medina, La imprenta en Manila, 68-69; and Santos, "Juan de Paz", for a list of his works. 
chapter, the Real Audiencia, and the Hermandad de la Misericordia, as well as private individuals. ${ }^{30}$ For example, the dean of the cathedral chapter and its individual members consulted him on matters concerning the collegial body and judicial cases, and generally heeded his opinions. The high regard for his opinion is evidenced even in the work of ad hoc committees composed of representatives from different religious orders, which were constituted by the chapter for cases of the utmost importance. ${ }^{31}$ Later generations of Dominicans made use of Juan de Paz's consultas as an authoritative reference in legal opinions and moral cases. Occasionally, they registered disagreement with him in matters of principle or cited the different socioeconomic context in which he wrote. ${ }^{32}$

His first published work (Manila 1689, reprinted in Seville in 1682 and 1687) was devoted to questions on doubtful practices of the newly Christianised communities in northern Vietnam (Tonkin), similar to the issues of the Chinese rites controversy. In effect, Paz made the preliminary study for the consultation that was subsequently sent to Rome. His second published work, Consultas y resoluciones, varias teológicas, jurídicas, regulares, $y$ morales, became reference material for officials in the archipelago, particularly for those who, as newcomers, were unfamiliar with the local context, such as the oidores of the Audiencia of Manila. ${ }^{33}$ The introductory consulta explained that expert opinion affecting the internal forum, as in cases of conscience, was also needed in contentious matters within the purview of public jurisdiction (figure 8.1). ${ }^{34}$

Francisco de Acuña, a former student of Juan de Paz, assisted in the publication of the consultas. To his mind, he was helping to fulfil the desire of many people. After the publication of the Consultas, Paz was denounced to

30 Salazar, Historia de la Provincia de el Santísimo Rosario, 729-731. Consultas addressed by $\mathrm{Paz}$, and some bearing his signature, are scattered in different manuscript sets in the archives of the Dominican province in Manila. AUST, Becerros, t. 26, 28 and 29.

31 AUst, Libros, t. 53, 66 and 67; Anales eclesiasticos de Philipinas, vol. 1, 240-242 and 254256; vol. 2, 48-5o and 58-6o.

32 For example, AUST, Folletos, t.14.12. Cited are explanations from Juan de Paz and Antonio de Anunciación, a Carmelite, regarding solitas; and AUst, Libros, t. 20, fols. 9v, 30v, $52 \mathrm{v}$, and 54 r.

33 Villarroel, A History of the University of Santo Tomas, 131-32; Salazar, Historia de la Provincia de el Santísimo Rosario, 731-732. For an introductory study of Consultas, see Molina, "The Dominican Fr. Juan de Paz", 313-350. The author's perspective is historiographical as she used the different consultas as a window into the Spanish colonial period in the Philippines.

Paz, Consultas, $1-5$. 


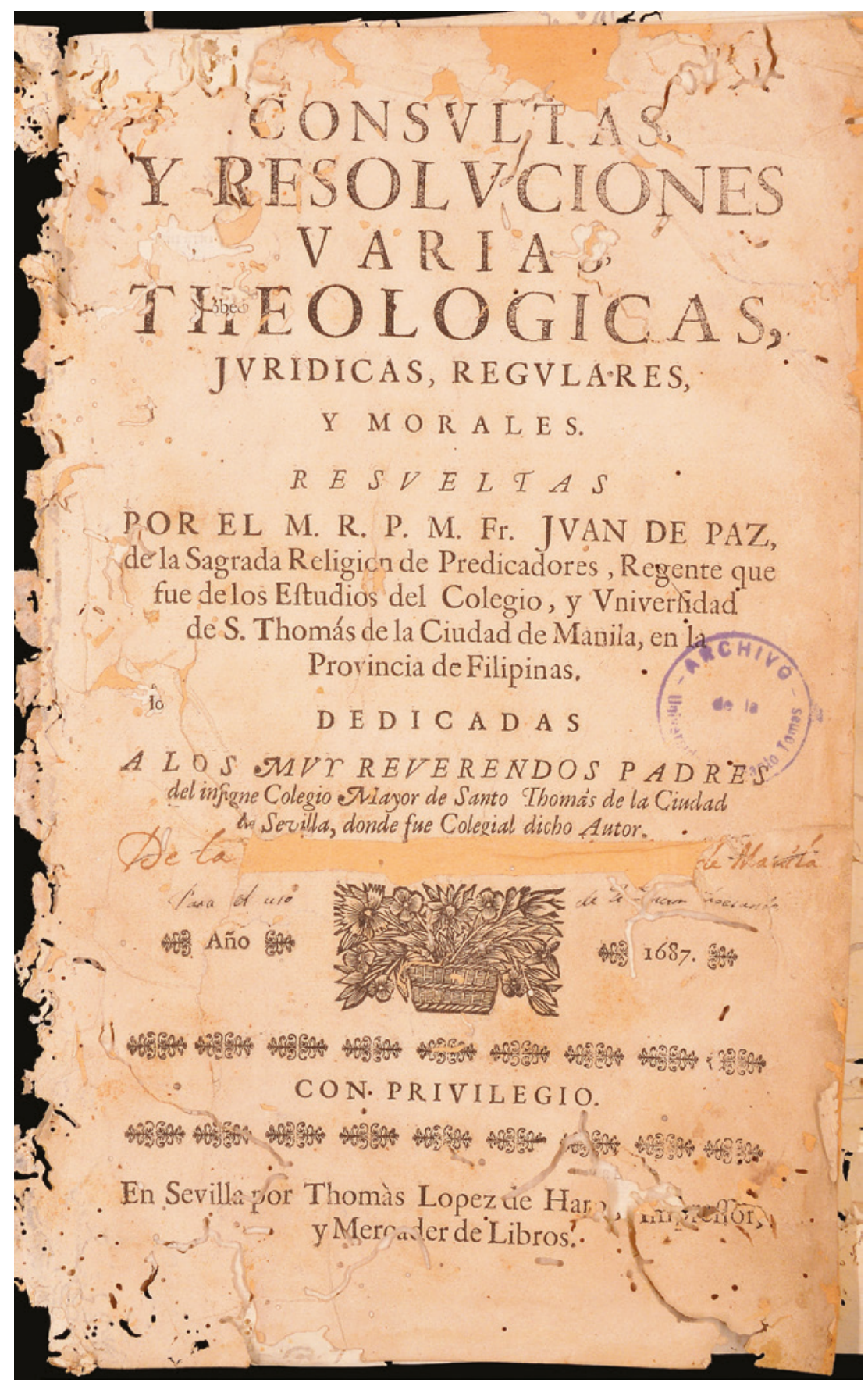

FIGURE 8.1 Juan de Paz, Consultas y resoluciones, varias teológicas, juridicas, regulares, y morales [...], Seville, 1687: Thomas Lopez de Haro (Archivo de la Universidad de Santo Tomas, Libros, 202a), title page 
the Dominican Master General and summoned to Rome, ostensibly for leaning towards probabilism. He was also accused of illicit dealings with foreigners because, according to his biographer Salazar, he had accepted consultations from beyond the Philippines. Because his outbound ship floundered in Philippine waters in 1692, Paz never made it to Rome and stayed in the Philippines until his death six years later. ${ }^{35}$ That he died in oblivion seems to be indicated in the single line devoted to him in the actas of the provincial chapter of $1700 .{ }^{36}$ Nonetheless, Paz continued to receive consultations after he returned. ${ }^{37}$ The trajectory of Paz in his later life might be a possible explanation why the 1745 edition was published in Antwerp and not in Spain or the Philippines. On the other hand, that a second, expanded edition was made might indicate significant demand for the book.

As Acuña explained in the introduction of the volume, he arranged the questions into the different aspects of restitution as an act of commutative justice, which he deemed to be of great importance. The last chapter comprised matters pertaining to the Brotherhood of the Santa Misericordia, which administered bequests, last wills, and testaments, matters essentially pertaining to restitution. He must have considered this type of private institution important enough to provide a normative reference for it not only for Manila but also for other parts of the Iberian world where similar entities existed. The 1745 edition included an additional, posthumous chapter that reflected the variety of affairs about which Juan de Paz was consulted. ${ }^{38}$

Since the first edition of Consultas revolved around questions of restitution, as far as marriage was concerned, it did not include inquiries directly affecting the sacramental character of marriage or its canonical form. The consultations concerned marriage promises and the exchange and transfer of goods and property such as dowries and arrhae, inheritance, and the condition of married slaves. However, the additional chapter in the 1745 edition did not adhere to the framing structure of restitution, and so we find cases pertaining to canon law, particularly the conditions for valid marriage.

35 Salazar, Historia de la Provincia de el Santísimo Rosario, 732-734; Santos, "Juan de Paz", 287-288.

36 Acta capitulorum, vol. 2, 10.

37 AUst, Libros, t. 23.

38 An addendum to Acuña's explanation of the organisation of chapters indicated the additional chapter, whose contents were sourced from the archives of the Convento de la Pasión in Madrid. The criteria of selection were not mentioned. 
Central to Acuña's argument for publishing his mentor's work in Seville was the precise need for a sound reference with which to resolve moral-juridical cases in the colony. That his confreres in Manila contented themselves with the books that came from Europe "aunque miren las cosas de lexos", was the very reason for the need to publish the Consultas "que no mira las cosas desde lexos ... sino que las mira, y toca muy de cerca". ${ }^{39}$ Likewise, the prefatory remarks and approvals that were obtained from Seville for the first edition recognised the value of Acuña's endeavour to save the distance, both geographical and normative, of which they seemed acutely aware, and thereby to localise the Spanish and European. The authorities of the Colegio Mayor de Santo Tomás in Seville captured it thus,

aunque la aplicación es nueva por la novedad de la materia, los principios generales en que estriva son assentados, y comunes, o ya sea de Theologia, ò ya de Canones, ò Leyes ... De suerte que, siendo las mas resoluciones de materias nuevas, son sacadas de principios antiguos. ${ }^{40}$

The normative value that Paz's contemporaries attached to his work was based on their appreciation of his breadth of learning in the fields of normative knowledge, his familiarity and insight into Philippine culture and society, and his ability to apply the former to the latter. A prefatory remark in Consultas reads, "Tanta era la universalidad de noticias deste Autor: y no parece menos la del nuestro en este presente libro, pues parece una Biblioteca compuesta de varias facultades". ${ }^{41}$ An authoritative opinion was usually based not on one but several, whose views converged. Even so, shared opinions could be contradicted by another group of authors, differences which the moral theologian had to navigate in order to arrive, at the very least, at the level of the probable, and to choose the solution most appropriate to each situation in all its specificity. ${ }^{42}$ The method used by Juan de Paz as well as Francisco Martínez exhibited the characteristics of the ars inveniendi that Duve discusses thoroughly,

39 Acuña, "Carta dedicatoria" in Paz, Consultas.

40 Paz, Consultas, "Aprobacion del insigne Colegio Mayor de Santo Thomas de Sevilla".

41 Paz, Consultas, "Aprobacion del insigne Colegio Mayor de Santo Thomas de Sevilla".

42 As Tau Anzoátegui qualified, the multiple citations were not meant merely to display erudition: "era un elemento necesario en el tratamiento de toda cuestión controvertida o en el desarrollo de la argumentación”, El jurista en el Nuevo Mundo, 105. 
indicating that these two moral theologians formed part of the epistemic community that the School of Salamanca comprised.

\section{$6 \quad$ Translating Custom ${ }^{43}$}

In the lowland Philippines, the Spaniards encountered marriage promises signified by tokens of suitors' commitment. Missionary literature referred to it as a dote given by the prospective bridegroom to the woman's parents. Such usage was consistent with colonial legal terminology in the 17 th and 18 th centuries. ${ }^{44}$ Colonial ethnographies mentioned the corresponding indigenous terms such as bugei (bugay) in Visayan and bigaycaya (bigay-kaya) in Tagalog. Modern anthropology has coined the terms "brideprice" and "bridewealth" to capture its sociocultural meaning more closely. 45 William Henry Scott has described marriages of datus or native chieftains in which the level of importance depended on the brideprice as "political events creating new alliances". ${ }^{46}$ In the Philippines in general, personal service (bride service) in the household of the bride's family constituted part of the bride price, signifying as well the bridegroom's capacity. Indigenous customary law had provisions for cases of the non-fulfilment of marriage promises: imposing a penalty on the reneging party. The reneging party also had to cover the expenses incurred for the celebration of the betrothal. ${ }^{47}$

Juan de Paz was asked why his opinion in a case of a defaulting bride was to make her pay a penalty. ${ }^{48}$ The consultation cited Tomás Sánchez's opinion to

43 With regard to indigenous custom, see Tau Anzoátegui's differentiation between the notion as conceived from the European legal tradition, specifically the jus commune, and the nature of indigenous custom as a socio-juridical order more closely connected to religion, natural forces, and traditions than was the case in medieval Europe. El poder de la costumbre, $77-78$.

44 The compilation of indigenous customary law made by the Franciscan Juan de Plasencia was promulgated in an auto acordado of the Audiencia of Manila in 1599 to govern court cases involving Philippine natives (see Hidalgo Nuchera, Los autos acordados de la Real Audiencia, 35). The author used dote consistently to refer to the token of commitment of the prospective bridegroom.

45 See Evans-Pritchard, "An alternative term"; Vroklage, "Bride price or dower"; and Dalton, "Bridewealth" vs. 'brideprice".

46 Scott, Barangay, 141-142.

47 For Visayan customs, see Alzina, Una etnografía de los Indios Bisayas, 235-236. The practices in concerting marriage and bridewealth of the Tagalogs and Pampangans of Luzon were very similar to each other as well as to the Visayans'. See Pérez, "Fr. Juan de Plasencia", 74 and Hidalgo Nuchera, Los autos acordados de la Real Audiencia, 91. 
the contrary: that to impose a penalty in such cases was illicit with respect both to the internal and external forum. ${ }^{49}$ To begin his exposition, Paz presented the differing opinion of later canonists (Leandro del Santísimo Sacramento, Antonino Diana, and Basilio Ponce de Leon). Then he proceeded to explain that the basis of his argument was established in civil and canon law, ${ }^{50}$ with whose spirit Sánchez essentially agreed: no penalty should be imposed on the party who broke the marriage promise with just cause because of its potentially coercive effect vitiating freedom of matrimonial consent.

How to resolve this apparent contradiction between the law and his opinion? Paz carefully distinguished between a simple promise and the arrhae (arras). He closely followed Gregorio López's commentary on the Siete Partidas (5.11.39), prohibiting the penalty for breaking the marriage promise. López distinguished between arrhae in its juridical sense, and a simple promise which was of less import and broken more easily. The arrhae signified a weightier commitment to marriage in the future and could therefore be subject to the penalty of forfeiture, in the present case, by the woman who had breached the promise for flimsy reasons. ${ }^{51}$

The Jesuit Francisco Ignacio Alzina wrote in the 17th century that among the Visayans in the Philippines, any party that reneged from fulfilling the marriage agreement was liable to pay a penalty (hingisul), which was sometimes set when the marriage agreement was made. From his experience as parish priest, he knew that if the agreement had been made by the parents without consulting their children, the possibility of reneging existed. And to give due allowance to the children's freedom, when it was verified that the reneging party had acted freely and was not obliged by his or her parents, he tried to dissuade them from imposing the penalty. The reason for this was in accordance with the legal prescription to avoid potentially coercive circumstances which made for a bad marriage. On the other hand, if the reneging party had been a free party to the agreement, he or she was made to pay the penalty. And he added that some were happy to pay the price just to be free to marry someone they preferred, knowing that a standing matrimonial agreement with one party was an impediment to marriage with another. ${ }^{52}$

To complicate matters, Paz was told that the arrhae in question was actually the dowry (dote), indicating that he might have committed an error in judgement. ${ }^{53}$ His reply incisively identified the semantic confusion. He was

49 Sánchez, De sancti matrimonii, lib. 1, disp. 30.

$50 \quad$ Liber Extra, 4.1.29; and Digest, 45.1.134; Codex, 5.1.5; Partidas, 5.11.39.

51 López, Las Siete Partidas, 5.11.39. The penalty imposed was just according to Codex, 5.1.5.

$5^{2}$ Alzina, Una etnografía de los Indios Bisayas, 235-236.

53 Paz, Consultas, 282-283. 
familiar with indigenous custom and readily identified the so-called dote as corresponding to the Spanish concept of arras, taking the definition from the Siete Partidas (4, 11, 1) - "como peño que es dado entre algunos, porque se cumpla el matrimonio que prometieron de fazer" - and also invoking Roman law. ${ }^{54}$ Pursuing this argument, he insisted on reality as referent "porque las leyes no se ponen para las palabras, sino para los contratos, y cosas que realmente se tratan". To strengthen this point, he mentioned a series of citations from jus commune about the meaning of words and Gregorio López's iteration of the meaning of arrhae as a token of future marriage.

In Philippine practice, distinction was made among objects given as tokens symbolising betrothal, gifts of affection, and those (including bride service) that properly constituted arrhae and were recognised as such. In lawsuits in which the litigants demand the restitution of objects or service given to the prospective spouse, this distinction was sometimes used by the litigants to prove whether a marriage agreement had been made or not. In the case between Ygnacia de Sta. Maria and Servando de los Santos, natives of a Tagalog town, who demanded fulfilment of a marriage promise with her daughter Maria de la Concepcion, the mother denied that a betrothal had ever been celebrated, saying that the suitor's offer to give gifts and to plough a piece of land simply signified his intention to court her daughter and not an earnest for future marriage, "pero creimos que fuese de puro cariño pues nacia de mera voluntad, sin qe le hiciesemos la menor insinuacion, ni nadie le impeliese a ello". 55 In cases of breach of promise, the demand for restitution of gifts was usually heeded for their symbolic value as well as for their material value, as the long lists of them and their price in pesos and reales indicate. Bride service, as part of arrhae, could be quantified in the wages paid to workers, food provided for them, and the rental of farm animals. Otherwise, as Juan Pérez expressed it, his son Florentino's seven months of service in Juliana's house would turn out to be "without value". ${ }^{66}$ The matter of restitution is not recorded at length in ecclesiastical court proceedings, an indication that it was largely peripheral to the matter at hand, properly pertaining to civil jurisdiction. ${ }^{57}$

54 Codex, 6.43.2; Liber extra, 5.40.6 and 5.40.8.

55 AAM, Box 14.A.3, fold. 12 (b).

$56 \quad$ AAM, Box 14.A.3, fold. 12 (a).

57 In other cases, the litigants were advised to refer the matter of gifts and arrhae to the civil jurisdiction. In one case where restitution that was owed for a breach of promise was impeding the legal resolution and subsequent marriage of a woman to another party, she requested that the matrimonial lawsuit be resolved per se and the matter of restitution be settled separately, presumably under civil jurisdiction. 
Hitherto we have ignored the extent of Juan de Paz's influence on colonial matrimonial jurisprudence and, as discussed, of the semantic clarification he made. Nonetheless, his commentary demonstrated that even when concepts were muddled in common usage, indigenous customs were accommodated to juridical concepts in Spanish law. Moreover, matrimonial lawsuits processed in the ecclesiastical court suggest that these concepts were delineated and differentiated with sufficient clarity to guide judicial processes and decisions.

Another case demonstrates the parameters by which indigenous customary law was assessed. ${ }^{58}$ It examined whether a man who had married again after his first wife had died was duty-bound to ask for the property (land and farm animals), and its fruits, which he had given as a "dote" to his wife. The resolution proposed and consulted by Paz was affirmative because it was in accordance with the custom that even though the parents received the "dote" (bridewealth) from the bridegroom, it was given to their daughter on their deaths and then later was inherited by her children. Furthermore, the enjoyment of usufruct by the husband and the eventual transfer of property to the children of the first marriage were supported by Roman law regarding second marriages, which Spanish law followed. ${ }^{59}$ "Es cosa muy conforme a Derecho, a la razon natural, y a la costumbre de los naturales, que los bienes que dá el que se casa se reserven para los hijos de aquel matrimonio [...]" This felicitous coincidence of norms was then followed by an exposition of the variations of practice in different provinces on the island of Luzon: in some, the dowry was given to the married couple after they had children; in others, when the parents saw that they were capable of managing their finances, with the wife's parents supporting the couple until that time. The case under consultation referred to the practice in the province of Pampanga, which did not differ much from the others. ${ }^{60}$ In sum, whatever custom was prevalent, the executor of the will of the first wife should give the husband part of the bridewealth that consisted in land and animals. As for the money portion, he should return only half to the surviving husband, since it was assumed that the bride's parents had paid for the wedding and wedding dress. Likewise, the value of the usufruct during the lifetime of the in-laws (the wife's parents) need not be restored to the husband,

58 Paz, Consultas, 681-682.

59 Codex, 6.6o.4 and 5.9.4. To strengthen his position, Paz cited medieval and early modern commentaries on them as well as Spanish legislation (Leyes de Toro and the Nueva Recopilación).

6o Regarding the customary law of the Pampangans on this matter, see Pérez, "Fr. Juan de Plasencia", 74-75 and Scott, Barangay, 247. On the Tagalog custom, see Pérez, "Fr. Juan de Plasencia", 67-68. 
which was apparently the local practice. However, the husband had the right to receive the value of the usufruct gained from the time of the death of his inlaws and should administer these properties until the children were of age. In this way, indigenous customary law was corroborated and articulated according to European juridical terms.

\section{$7 \quad$ When Custom Was Inadmissible}

From the early 18th century onwards, the moral issue identified as arising from the prestations of the dote and bride service as prenuptial requisites led to a legal prohibition. Governor General Domingo de Zabálburu issued a decree on 8 April 1704 at the petition of the archbishop of Manila, fray Diego Camacho. ${ }^{61}$ This was a case of collaboration between the civil and ecclesiastical jurisdictions to promote public morality, where the punitive force of the secular authority was deemed more effective than moral injunctions alone. The decree essentially applied law 6, title 1, book VI of the Recopilacion de las leyes de Indias to the Philippines "Que los indios no puedan vender sus hijas para contraer matrimonio". ${ }^{2}$ Hitherto we have not found an earlier legal intervention on the matter. The rationale for the original was to preserve women's freedom to marry because they were wont to obey their parents, who oftentimes accepted the suitor who could give the most bridewealth. The consequence was marriages without love or fidelity, and domestic abuse, and this lack of peace in the home was considered to be a matter of public importance. Zabálburu's decree focused on prohibiting the custom of bride service because of its immoral consequences "contra la Castidad, como contra la Justicia". The first referred to women who ended up with tainted virtue, and therefore dishonour, and the second to the men who would had laboured in vain without winning a bride. The different penalties established for the various breaches

61 On the repeated denunciation of these practices, see Garcia, "Particular discipline on marriage", 20-32.

62 On the doctrinal background of this law, see Aznar Gil, "La libertad de los indígenas". This royal decree confirmed the Ordenanzas para el buen gobierno de los indios, written by Juan Maldonado Paz, oidor of the Audiencia of Guatemala, during his visitation of the province of Verapaz, dated in Camaiaque, 19 December 1625. Royal confirmation of the ordinances, addressed to the governor of Guatemala, was issued on 29 September 1628. Tovilla, Relaciones histórico-descriptivas. Daisy Rípodas Ardanaz (El matrimonio en Indias, 239, footnote 49) also cited the related law 14, title 6, book 6 of the Recopilación de leyes de Indias, which was a royal decree addressed to the Audiencia of Peru, 17 December 1551, "Que los caciques no reciban en tributo á las hijas de sus Indios". 
were a direct translation from the American context: a commoner or timagua (macegual in the original) was to receive 50 lashes, be forbidden from holding public office, and surrender the value of the bridewealth received to the public treasury; while a principal was to be demoted to the status of timagua. ${ }^{63}$ This decree would form part of the "Ordinances of Good Government" that were drafted by subsequent governors general. ${ }^{64}$

The question of the freedom of marriage reappeared in the Tagalog province of Bulacan in 1733 and later in the ordinances for the northern provinces of Luzon (Cagayan and Ilocos), which were formulated by the oidor of the Audiencia of Manila, Ignacio Arzadún y Rebolledo, as a result of the visitation he carried out. The thirty-third ordinance was intended to regulate the "abuse" whereby the dote (bridewealth) was set at a prohibitively high price unattainable for most men, with the result that few were married in church. In the same vein as the royal decree that Zabálburu invoked, this local law sought to eliminate the custom altogether by prohibiting the dote. ${ }^{65}$

The continuing creation of norms that centred on bridewealth and bride service constitutes a vivid example of the legislative process that sought to address local circumstances and practices while trying to administer the sacrament of marriage in accordance with Church law, and not least the Tridentine decrees. It mirrors to some extent the process of matrimonial legislation in the Americas which, as Jose Luis Egío points out in his study on Alonso de la Vera Cruz in this volume, "resulted from an intense dialogue between jurists and theologians".

Francisco Martínez’s Opinion ${ }^{66}$

The repeated injunctions and admonitions during the 18th century indicate the slow progress in this battle against custom. ${ }^{67}$ Around the turn of the

63 AUST, Libros, t. 6o, fols. 133-134.

64 It was added to Corcuera's (1696) and retained in those issued by Raón (1768), which were published by Aguilar in 1803. Blair and Robertson, The Philippine Islands, vol. 5 .

65 Archivo Provincial de los Dominicos, Ávila (APD), leg. 1/79, Pangasinan, t. 9, doc. 7, fols. 171r-v. The same ordinance was issued for the province of Cagayan in 1739. The ordinances for Bulacan are found in Archivo Franciscano Ibero-Oriental (AFIO), 88/40.

66 AUst, Libros, t. 62.

67 See the decree of the Provincial Council of Manila on matrimony (actio v, tit. 1, decr. 7 §iiv) in P. Bantigue, Provincial Council of Manila of 1771, 121-122; and of the Synod of Calasiao, which made reference to the Council of Manila, in Philip Smith, "The acts of the Synod of Calasiao, 1773", 104-105. For the various sources of admonitions, see Camacho, "Marriage in the Philippines", 160-161. 
century, we find the Dominican Francisco Martínez ${ }^{68}$ addressing this matter. The extant writings of this friar, which seem to have survived serendipitously, afford a glimpse of the work of a vicar of a missionary district. They consisted of moral cases, which were prepared monthly in the years that he was vicar of the mission of Aritao in the province of Nueva Vizcaya in northeastern Luzon; replies to consultations on pastoral and moral matters; and homilies. He wrote veritable treatises on the question of whether the parents who received payment or personal service from the prospective bridegroom were obliged in conscience to restitute what was received, whether or not the marriage took place. Related to this question was the responsibility of parish priests who tolerated the practice of bride service and, worse, if the event led to the cohabitation of the future spouses. It cannot be ascertained if these cases were written as responses to consultas or cases for moral theology classes. Having pastoral experience in the mission territories of the province of Nueva Vizcaya in north-eastern Luzon, ${ }^{69}$ Martínez's impassioned opinion probably derived from first-hand knowledge of the detrimental consequences of insufficient matrimonial consent - he cited from experience - due to the practices in question. Throughout his exposition, he repeatedly called attention to the violation of the cited law in the Recopilación.

These moral issues emerged from construing the matrimonial prestations of bridewealth and its complementary bride service in basically economic terms. This interpretation became fixed - as far as colonial authorities were concerned - upon the prohibition of the aforementioned practices by the ordinance of 1704. Perhaps this interpretation was due to the fact that the bridewealth went to the bride's parents and family, instead of contributing to the marriage at the outset; however, as has been mentioned in one of the previous cases, the parents actually gave part of it to the married couple. Another reason might simply be that it was diametrically opposed to the European institution of dowry. The confusing use of the term dote, which Juan de Paz had untangled, persisted in official discourse.

Martínez described the indigenous "dote" as an agreement with the bride's parents which stipulated a value they were to be given in exchange for their

68 Francisco Simón Martínez Pantaleón (1755-1823) was born in Jaén. Upon arriving in the Philippines, he was assigned to the mission of Ituy y Paniqui $\left(1785^{-1789)}\right.$ and later Aritao, all in the province of Nueva Vizcaya. After serving as procurator of the Dominican province, he returned to the missions in Nueva Vizcaya. In 1802 he was appointed provincial vicar of that area. Ocío and Neira, Misioneros Dominicos, vol. 1, 526-527.

69 For a history of the Dominican missions in the province of Nueva Vizcaya, see Malumbres, Historia de Nueva Vizcaya and Historia de la Isabela. 
daughter; at its worst, he likened it to auctioning the daughter off to the highest bidder. As an example of how deeply rooted the custom was, he told the story of a priest who announced that he would not issue marriage banns for those who had rendered or would render personal service. Consequently, there were no weddings for an entire year or more, demonstrating the despotic authority of parents in deciding the marriage of their children, particularly daughters. His theoretical argument was therefore well-grounded on his experience of indigenous culture in the mission areas where he served. He was among the many missionaries including those in the Americas who, as Egío mentions in his chapter in this book, strove to draw the line between the tolerable and the unacceptable in the realm of marriage after conversion to Christianity.

Martínez proceeded to demolish the reasons for the practice, which, in his opinion, should therefore give way to the new law. Firstly, he questioned the indigenous notion of recompensing the mother for having nursed and raised a daughter against the premise that parents had a natural duty to provide for their children's needs. On this point, he cited several commentaries on canon law, the 18th-century moral theologian Paul Gabriel Antoine, and then the 17th-century commentaries on the Decretals by Prospero Fagnani and Manuel González Téllez. ${ }^{70}$ Next, he addressed the issue of commodification, of sale and purchase, by first establishing the requisite condition of rightful ownership. But since parents did not own their children, they could not lawfully sell them, especially for marriage. On the question of sale and purchase, Martínez cited the jus commune and the commentary of González Téllez, stressing the requirement of ownership for a rightful sale to proceed, and even then the purpose of the transaction should be lawful and just, without prejudice to others. ${ }^{71}$ What then was the nature of parents' relationship with their children and, related to that, the scope of their authority? For these matters, Martínez appealed to natural law as discussed by St. Thomas Aquinas and Aristotle. ${ }^{72}$ Starting with the definition of theft, he obliquely approached the relationship, demonstrating that the child was a part of the parent but not a possession and therefore, properly speaking, could not be stolen from them. More specifically, Aquinas used the term ius prelationis (the authority of a superior) with respect to domestic life and moral instruction, in accordance with Aristotle. The latter considered the child who was still a minor as part of the parent and

70 Antoine, Theologia Moralis Universa, vol. 2, 4.1; Fagnani, Commentaria in Primam Partem, Quoniam, 7 González Téllez, Commentaria Perpetua, vol. 4, 4.7.5.4.

71 Digest, 8.1.34.1; Codex, 4.35.21; González Téllez, Commentaria Perpetua, vol. 3, 3.21.2.

72 Thomas Aquinas, Quodlibet II, q. 5, art. 1; Summa Theologiae, 2.2 q. 66. art. 3; Aristotle, Nichomachean Ethics, 5, 6 (1134b). 
understood that the parent would not harm them precisely for that reason. Then, returning to the law in the Recopilación de las leyes de Indias, he noted how much care had been given to ensure fairness in the sale and purchase of animals; in that vein, he cited Juan de Solórzano Pereira on the need to guide the Indians like minors in their transactions. ${ }^{73}$

After establishing the moral grounds, Martínez focused on the central problem: the consequent lack of or doubtful consent of the children to the marriage arranged by their parents. He invoked civil and canon law, ${ }^{74}$ stressing particular consideration of the internal forum, especially in regard to tacit consent which might be mistakenly presumed. Perhaps based on his experience, Martínez counselled care in accepting the sincerity of children's consent, even if it was verbal. As a warning for those who neglected this point, he anticipated the double hell that awaited those who were forced into marriage: one in this life, and the other with the parents in the next. Finally, Martínez called for the strict enforcement of the law through the vigilance of parish priests, and also cited the Council of Trent's exhortation to secular authorities to defend the Church's rights and freedoms so that they too would support ministers in their duty in this particular case. In the face of the continuing abuse, where ignorance was not an excuse, it was urgent to apply the remedy of correction.

At the core of his arguments, Martínez deplored the practice of invoking custom - "que conserva resabios feos y abusos perniciosos del gentilismo" to keep the status quo: if custom went against natural and divine law, and against civil and canon law, it was bereft of all reason and therefore should not be tolerated. He reiterated this point vis-à-vis the utter disregard of the legal prohibition,

[...] pues basta darle una ojeada, teniendo ojo á otras las Canónicas y regias, y sin perder de Vista al derecho natural y divino, para conocer, que qualquier costumbre, que se pretendiese introducida, ó que se introduxese contra su prohibición, su mente, sus causas finales expresas, sería costumbre irracional, verdadera corruptela, lex mortis. ${ }^{75}$

Since the late 17th century successive bishops had issued norms prohibiting these practices, which would be reiterated in conciliar decrees in the late 18th century. Aside from the evils pointed out by Martínez, the Provincial Council

\footnotetext{
73 Solórzano, Política indiana, bk. 1, chap. 28.

74 Digest, 22.3; Council of Trent, sess. 24, Reformation of marriage, chap. 9; Cassiodorus, Variae, 7.4 . 
of Manila of 1771 identified the impediment arising from the promiscuous relationships of the prospective bridegroom, who rendered service in the woman's house, with her sisters. On the subject of the dowry called pasusu that was specifically given to the mother, the council noted that it had been a cause of postponing marriages. The council's approach was both remedial (the prompt celebration of marriage once assurance was obtained that there was no impediment) and punitive (the imposition of public penance on the parents and the man who rendered service, fines, and restitution). ${ }^{76}$ The Synod of Calasiao, held in the suffragan diocese of Nueva Segovia in 1773 , on the other hand took a more pastoral approach: it sought to moderate bridewealth to more affordable levels. ${ }^{77}$

The current state of research does not allow us to ascertain the effectiveness of civil and canon law in prohibiting such customs. Court cases from the midto late eighteenth century evidence the continuity of these prestations, particularly bride service, which were perceived as inherent to betrothals. On the other hand, there are indications that these laws were taking effect. The lawsuit mentioned above gave a paradoxical instance of how judicial means were applied by the suitor to regulate it. When the woman's parents demanded one more year of service after the seven months of work initially agreed upon had been rendered, the man's father demanded fulfilment of the marriage promise on the original terms. The judge ruled in their favour, noting, among other things, that the law had been violated. ${ }^{78}$

The prenuptial case mentioned above from the late 18th century provides a window into the dynamics resulting from indigenous consciousness of the law, pastoral considerations of the parish priest, and the process of law enforcement in this period. ${ }^{79}$ Maria de la Concepcion withdrew from a marriage agreement after marriage banns had been published and no impediments had been identified. According to testimonies, the real reason for breaking the marriage agreement was that the prospective bridegroom Servando de los Santos had not satisfactorily fulfilled his supposed obligations of bride service to the family. It transpired that, to avoid punishment for violating the prohibition of this custom, the man had indirectly rendered service by contributing to the materials for the house of his future in-laws, hiring hands to assist in the harvest, and providing food and drink to those who had laboured at harvest time. The fact that a betrothal had been established persuaded the priest that the couple

76 Bantigue, The Provincial Council of Manila, 121-122.

77 Smith, "The Acts of the Synod of Calasiao", 104-105.

78 AAM, Box 14.A.3, fold. 12 (a).

79 AAM, Box 14.A.3, fold. 12 (b). 
should be married; he was willing to reduce the cost knowing that the parents were poor. Based on the narrative, it may be presumed that at least part of the law's intention was fulfilled: the man's compliance must have prevented him from living in the house of his future in-laws. The parish priest's report mentioned that a few years ago he had urged the town authorities to strictly implement the prohibition of personal service. Indeed, since that time, several violators had been punished. An appended condition to the local law stated that should the betrothal be broken by the woman or her parents, the man who served them would be free from punishment, in order to encourage violators to tell the truth post factum. The case of this town might have parallels in other towns, affording a glimpse into a legal space in which implementation and accommodation occurred at the same time.

\section{$9 \quad$ Lawful Marriage for the Salvation of Souls}

The two cases in this section indicate how knowledge of local circumstances specified and afforded greater certainty in applying moral and canonical principles and laws. Geographical knowledge in particular proved to be useful.

The first case involved a slave couple from the province of Cagayan in the north-eastern part of Luzon. They had been married with the master's permission, however, the man turned out to be troublesome, taking long absences which became vexatious to the owner and reduced conjugal life. The question posed was whether, given his disposition, it was justified to sell him in another place, thus separating him from his wife. ${ }^{80}$ Paz juxtaposed the various dimensions of slave marriage, stating on the one hand the principles of the natural freedom of marriage vis-à-vis the slave condition, and on the other, the mutual moral responsibilities between master and slave. In the end he offered various options which the complexity of the question elicited.

The primary value of conjugal life should govern the master's treatment of married slaves, whether they married with his permission or not. Therefore, it would not be right, in principle, to sell the slave to a distant place unless there was grave reason. The master had the obligation to take care of the well-being of his property, in this case, by facilitating conjugal life. Marriage being a natural right, masters could not impede their slaves from marriage or its corresponding duties. ${ }^{81}$ Consequently, the master assumed the moral responsibility

$80 \quad$ Paz, Consultas, 105-108.

81 Thomas Aquinas, Summa Theologiae, p. 3, q. 52. art. 2. As a slave he was subject to the master, but with regard to nature they were equal. 
of facilitating conjugal life. ${ }^{82}$ If that was prevented by physical separation, he had the obligation to buy back the slave even if was costlier, or to sell the wife to where the husband was, unless the spouses ceded their natural right. On the other hand, it was possible that sufficient motive existed for selling the slave far away. Paz used the analogy that even free men were at times obliged to be away from their wives and homes for years without it causing them to sin. Therefore, the master could take the slave with him in a prolonged absence. After establishing the basic freedom of marriage, Paz discussed the problem of the slave's condition. As elaborated by Aquinas, slavery impeded the attainment of the goods of marriage, that is, the free execution of its primary acts, particularly cohabitation and the fulfilment of conjugal debt, and children inherited their parents' condition. Since it was the slave's duty to serve, the master could rightfully call on him even in ways that interrupted cohabitation. For this latter point, which Paz developed into resolutions, he gave a more contemporary flavour by citing Martín de Azpilcueta, Enrique Henríquez, and Pedro de Ledesma. ${ }^{83}$

Having established these principles, Paz began to apply them in combination. If the master was a married merchant who went on long journeys himself, he could bring the married slave with him or, for that matter, send him to faroff places. The master could justifiably do all this even if he had agreed to the marriage with its consequent obligations. At this point, Paz proceeded along the open-ended statement of Aquinas that, depending on the circumstances, the slave's obligation to the master or to the spouse might take priority. In sum, the slave's natural right to marriage was still not absolutely above grave reasons for overruling that right.

Paz then examined to the specific circumstances of the case: what remained to be considered was whether the reasons referred to were grave enough to justify selling the slave in a distant place. Geography played a significant part in the options he explored. In the first instance, he circumscribed the place of sale to the province of Cagayan where the slave couple were originally from, and where, even if the towns were far apart, it was not impossible for the husband to travel to be with the wife. Separating him from his wife in this way would alter the present situation little; at the same time, the master could get rid of the delinquent servant. However, the master's interest was not sufficient cause to sell the slave outside the province of Cagayan. Should it be the case

$82 \quad$ Digest, 1.6.1; Codex, 3.38.11.

83 Thomas Aquinas, Scriptum super Sententiis, lib. 4, dist. 36, art. 1-2; Liber Extra, 4.9.1. Paz cited many medieval and early modern authors to support this point, including Azpilcueta, Manual, cap. 22, n. 34; Henríquez, Theologiae Moralis, l. 11, c. 10, n. 4.; and Ledesma, Tractatus de Magno Matrimonii, q. 52, art. 2, dub.1. 
that the husband had a concubine elsewhere (which might be the reason for his frequent absence), it would then be licit to sell him to a far-away place, albeit subject to his wife's consent. According to Scripture and canon law, the adulterer lost his right to ask for the conjugal debt from his wife and to cohabitation. As a last option, if no one from Cagayan was willing to buy the slave, he could be sold outside that province because he had become a liability to his master. Each absence was tantamount to theft for not having rendered due service. Also, despite the greater separation resulting from such a sale, the master was not responsible for the moral damage to the marriage as the husband had already wilfully caused it through his frequent absence.

Paz laid down as a general condition that given the possibility of selling the slave within the province, it would not be licit to destine him for a more remote place. In sum, it was more favourable to preserve the marriage by facilitating contact between the spouses and thereby minimise the occasion of extramarital relations. The long opinion sought to make the defence of marriage as a fundamental freedom compatible with a master's property rights over slaves. It dealt with intersecting questions of justice within the accepted framework of the master-slave relationship, and ultimately sought the salvation of souls. It was realistic in its appreciation of human foibles and the geographical context.

The second case was more straightforward, consisting of the proposed solution of marriage of two Muslim women, who were to be baptised, with foreign merchants in order to regularise their relationship (embarraganados). ${ }^{84}$ The rules of marriage of itinerant persons would be applied to them and they could marry in the port of Cavite as no parish existed in the women's place of origin (Bantán) and the men themselves did not belong to any parish. The parish of Cavite was the best place for the marriage since the men spent more time there. Nonetheless, the directive of the Council of Trent (sess. 24, Reformation of marriage, chap. 7) should be followed to avoid clandestine marriages: the parish priest of Cavite was under the strict obligation to obtain prior permission from the bishop to officiate the weddings. The desire to stop to sinful relationships by facilitating Christian marriage undergirded this resolution. It succinctly cited the commentaries of Enrique Henríquez, Basilio Ponce de León, and Tomás Sánchez on Tridentine doctrine in this matter. ${ }^{85}$ Paz agreed entirely with the proposed, as it was in accordance with canon law and the Council of Trent, remarking that he had nothing to add.

84 Paz, Consultas (1745 ed.), 586.

85 Henríquez, Theologia Moralis Summa, lib. 11, cap. 3. n. 3; Ponce de León, Sacramento Matrimonii Tractatus, lib. 5. cap. 16. n. 14; Sánchez, De Sancto Matrimonii, lib. 3, disp. 25, n. 14. 
The consultas and pareceres of Juan de Paz and the moral case of Francisco Martínez that have been analysed in this study provide a windowinto the production of legal and moral opinions and treatises at the University of Santo Tomas in Manila. It was a function that was of unimaginable importance in terms of public impact if we are to judge from the range of matters they addressed. It represented their moral authority in the different sectors of colonial society which evidently valued the moral dimension of both private and public affairs. Duve's point on the privileged position of theologians, whose ultimate concern was the cura animarum which therefore placed practically all human affairs within their purview, can be appreciated in the Philippine colony. We have just begun to discover the extent to which the work of these two Dominicans influenced jurisprudence and moral theology, which in turn contributed to the barely perceptible processes of shaping social and moral normativities.

The works of Paz and Martínez provide a glimpse of the normative content and discursive method which characterised the intellectual and cultural tradition of universities in Spain and America, a tradition that was transplanted to the Philippines where its pragmatic dimension addressed local specificities. The practice of citing authors to support moral and legal positions inserted the moral theologian into the continuing conversation between experts who argued with and listened to each other with a view to arriving at a reasonable synthesis. On the far side of the Pacific, Manila was not isolated from the circulation of ideas conveyed by people and the books that travelled with them. The normative questions examined in this chapter evince how, in the Philippine ambit, the School of Salamanca might be understood as a communicative practice, as Duve analyses at the beginning of this volume.

The range of sources used in these cases exemplified the integral vision of law - in which divine law provided the basis of natural and positive law wherein civil and canon law were complementary, and moral theology played a preponderant role. Marriage, being essentially a bond between persons, inevitably involved questions of justice in its different dimensions and its ramifications for the family. Its sacramental character was deeply relevant to the salvation of souls. In the task of Christianising a society, marriage was to be governed by a conception of law which integrated the human and divine, manifested in the alignment of positive with natural law as well as between secular and ecclesiastical law. In accordance with this scheme, Paz and Martínez assessed indigenous marriage and its cultural context, accommodating or rejecting them, translating or mistranslating them into European terms. In this way, they expanded the horizons of orthodoxy in the colonial setting. 


\section{Bibliography}

\section{Manuscripts}

Archives of the University of Santo Tomas, Manila (AUST), Becerros, t. 1.

AUST, Becerros, t. 25 .

AUst, Becerros, t. 26.

AUST, Becerros, t. 28.

AUST, Becerros, t. 29.

AUST, Folletos, t. 14.12.

AUST, Libros, t. 20.

AUST, Libros, t. 23.

AUST, Libros, t. 37.

AUST, Libros, t. 51.

AUST, Libros, t. 53 .

AUST, Libros, t. 54 .

AUST, Libros, t. 60.

AUST, Libros, t. 62.

AUST, Libros, t. 63 .

AUst, Libros, t. 66.

AUST, Libros, t. 67.

Archivo Franciscano Ibero-Oriental (AFIO), 88/40.

Archivo Provincial de los Dominicos, Ávila (APD), 1/79, Pangasinan, t. 9, doc. 7 .

Archdiocesan Archives of Manila (AAM), Informaciones matrimoniales, box 14.A.3, fold. 12 (a), "Presentacion de Juan Pérez Principal del Pueblo de Malate sobre el Matrimonio que tiene pactado su hijo Florentino Pérez con una nombrada Juliana". AAM, Informaciones matrimoniales, box 14.A.3, fold. 12 (b), "Presentacion de Ygnacia de Sta Maria en q solicita se le ponga en livertad a su hija Maria de la Concepcion, q se halla depositada en las casas de las Recogidas por remision q hio el Parroco del Pueblo de Baras Fr Casimiro Pitarque de su persona con motivo del trato de casamto q con ella tiene celebrado con un nombrado Servando de los Santos".

\section{Printed Sources}

Anales eclesiásticos de Philipinas, 1574-1682. A Summary Translation, ed. Santos, Ruperto, 2 vols., Manila 1994.

Acta Capitulorum Provincialium Provinciae Sanctissimi Rosarii Philippinarium, Ordinis Praedicatorum ab anno 1588 a sua in provinciam erectione primo, 2 vols., Manila 1874-1877: Colegio de Santo Tomás.

Aduarte, Diego, Tomo primero de la Historia de la Provincia del Santo Rosario de Filipinas, Japony China de la Sagrada Orden de Predicadores [...], Zaragoza 1693: Domingo Gascon. 
Alzina, Francisco Ignacio, Una etnografía de los Indios Bisayas del Padre Alzina, ed. Yepes, Victoria, Madrid 1996.

Antoine, Paul Gabriel, Theologia Moralis Universa [...], Roma 1767: Antonius Zatta.

Aquinas, Thomas, Opera omnia, Corpus thomisticum, Pamplona 2000-2018.

Aristotle, The Nichomachean Ethics, eds. Ross, David and Lesley Brown, Oxford 2009.

Azpilcueta, Martín de, Manual de confessores y penitentes [...], Salamanca 1556: Andrea de Portonarijs.

Cassiodorus, Variae epistolae, ed. Hodgkin, Thomas, The Letters of Cassiodorus, London 1886: Frowde.

Corpus iuris canonici, eds. Richter, Emil Ludwig and Emil Albert Friedberg, Leipzig 1879-1881 (repr. Graz 1959).

Corpus iuris civilis, ed. Parsons Scott, Samuel, The Civil Law, 17 vols., Cincinnati 1932.

Fagnani, Prospero, Commentaria in Primam Partem Quinti Libri Decretalium, Roma 1661: Iacobus Feius.

González Téllez, Manuel, Commentaria Perpetua in Singulos Textus Quinque Librorum Decretalium Gregorii IX, vols. 3 and 4, 5 vols., Venezia 1699: Nicolaus Pezzana.

Henríquez, Enrique, Summa Theologiae Moralis Tomus Primus, Venezia 16oo:Damianus Zenarus.

Las siete partidas del Rey Don Alfonso el Sabio: cotejadas con varios códices antiguos por la Real Academia de la Historia, Tomo 3: Partida Quarta, Quinta, Sexta y Septima, ed. Martínez Marina, Francisco, Madrid 1807: Imprenta Real.

Ledesma, Pedro de, Tractatus de Magno Matrimonii Sacramento [...], Venezia 1595: Marcus Antonius Zalterius.

López, Gregorio, Las Siete Partidas del sábio Rey don Alonso el Nono, glosadas, Madrid 1789: Benito Cano.

Malumbres, Julián, Historia de Nueva Vizcaya y provincia montañosa, Manila 1919: Colegio de Santo Tomás.

Malumbres, Julián, Historia de la Isabela, Manila 1918: Colegio de Santo Tomás.

Paz, Juan de, Consultas y resoluciones varias theologicas, jurídicas, regulares, y morales [...], Sevilla 1687: Thomas López de Haro (re-printed Antwerp 1745: Hermanos de Tournes).

Ponce de León, Basilio, De Sacramento Matrimonii Tractatus [...], Venezia 1645: Combi. Recopilación de leyes de los reinos de las Indias, Madrid 1680: Julián de Paredes.

Salazar, Vicente de, Historia de la Provincia de el Santísimo Rosario de Filipinas, China y Tunking, de el Sagrado Orden de Predicadores. Tercera parte en que se tratan los sucessos de dicha Provincia desde el año de 1669 hasta el de 1700, Manila 1742: Colegio de Santo Tomás.

Sánchez, Tomás, De Sancto Matrimonii Sacramento Disputationum Tomi Tres, Venezia 1612: Giunta. 
Santa Cruz, Baltasar de, Tomo segundo de la Historia de la Provincia del Santo Rosario de Filipinas, Japón y China del Sagrado Orden de Predicadores [...], Zaragoza 1693: Pascual Bueno.

Solórzano Pereyra, Juan de, Política indiana [...], Madrid 1648.

Tovilla, Martín Alonso, Relaciones histórico-descriptivas de la Verapaz, el Manche, Lacandon, en Guatemala, ed. Prage, Christian (orig. Editorial Universitaria, Guatemala City 196o), http://www.wayeb.org/download/resources/tovilla.pdf.

The Canons and Decrees of the Sacred and Oecumenical Council of Trent, ed. Waterworth, James, London 1848: Dolman.

\section{Literature}

Aparicio, Ángel and Esther Majuelo, Catalogue of Rare Books. University of Santo Tomas, 4 vols., Manila 2001-2015.

Aznar Gil, Federico, "La libertad de los indígenas para contraer matrimonio en las Indias (siglos XVI-XVII)", in Ius canonicum 32 (1992), 439-62.

Bantigue, Pedro, Provincial Council of Manila of 1771, Washington, D.C. 1957.

Blair, Emma and James Robertson, The Philippine Islands, 1493-1898, 52 vols., Cleveland 1907.

Camacho, Marya Svetlana, "Marriage in the Philippines after the Council of Trent (Seventeenth to Eighteenth Centuries)", in Rechtsgeschichte/Legal History 27 (2019), $153^{-162 .}$

Dalton, George, “'Bride-wealth vs. bride-price”, in American Anthropologist 68:3 (1966), $732-738$.

Evans-Pritchard, Edward, “An alternative term for 'bride-price”, in Man 31 (1931), 36-39. Garcia, Excelso, "Particular discipline on marriage in the Philippines during the Spanish regime", in Philippiniana Sacra 8:1 (1973), 7-88.

González González, Enrique and Vicente Gutiérrez Rodríguez, Juan de Palafox y Mendoza. Constituciones para la Real Universidad de México (1645). Edición crítica, estudios e índices, México 2017.

González González, Enrique and Vicente Gutiérrez Rodríguez, El poder de las letras. Por una historia social de las universidades de la América hispana en el periodo colonial, México 2017.

Hidalgo Nuchera, Patricio, Los autos acordados de la Real Audiencia de las Islas Filipinas de 1598 y 1599, Madrid 2012.

Medina, José Toribio, La imprenta en Manila desde sus orígenes hasta 1810, Santiago de Chile 1896 (repr. facs. Valencia, n.d.).

Molina, Carlos, “The Dominican Fr. Juan de Paz as a source of historical information through his writings", in Unitas 53 (1980), 313-35o.

Ocío, Hilario and Eladio Neira, Misioneros dominicos en el Extremo Oriente, 1587-1835, 2 vols., Manila 2000. 
Pérez, Lorenzo, "Fr. Juan de Plasencia, y sus relaciones sobre la costumbre que los filipinos obserbavan en la tramitación de sus juicios civiles y criminales antes de la llegada de los españoles a Filipinas", in Archivo Ibero-Americano 40 (1920), 54-75.

Rípodas Ardanaz, Daisy, El matrimonio en Indias. Realidad social y regulación jurídica, Buenos Aires 1977.

Santamaría, Alberto, Estudios históricos de la Universidad de Santo Tomás de Manila, Manila 1938.

Santos, Edilberto, "Juan de Paz, O.P. (1622-1699): The oracle of Asia", in Philippiniana Sacra 22:2 (1987), 281-299.

Scott, William Henry, Barangay. Sixteenth-Century Philippine Culture and Society, Quezon City 2015.

Smith, Philip, "The acts of the Synod of Calasiao, 1773", in Philippiniana Sacra 5:1 (1970), 65-107.

Tau Anzoátegui, Víctor, El poder de la costumbre. Estudios sobre el derecho consuetudinario en América hispana hasta la emancipación, Buenos Aires 2001.

Tau Anzoátegui, Victor, Eljurista en el Nuevo Mundo. Pensamiento. Doctrina. Mentalidad, Frankfurt 2016.

Velasco, Vicente, "Apuntes para la historia de la teología en Filipinas", in Unitas 38:2 (1965), 233-247.

Velasco, Vicente, "Apuntes para la historia de la teología en Filipinas", in Unitas 37:4 (1964), 523-535.

Villarroel, Fidel, A History of the University of Santo Tomas: Four Centuries of Higher Education in the Philippines (1611-2011), 2 vols., Manila 2012.

Villarroel, Fidel, "The University of Santo Tomas Library. An historical outline", in Philippiniana Sacra 17:1 (1982), 76-95.

Vroklage, Bernhard, "Bride price or dower", in Anthropos 47:1-2 (1952), 133-146. 